\title{
Technical Study of Reducing Ground Vibration Levels on Overburden Blasting Activities in East Pit PT. Bungo Bara Utama Jobsite Kuansing Inti Makmur, Bungo District, Jambi Province
}

\author{
Husnu Hifzirridho ${ }^{1}$, Agustinus Isjudarto ${ }^{2 *}$, Rizqi Prastowo ${ }^{3}$
}

$\left\{{ }^{1} 1710016020 @\right.$ students.itny.ac.id, ${ }^{2}$ isjudarto@itny.ac.id, ${ }^{3}$ rizqi @itny.ac.id $\}$

\begin{abstract}
Department of mining engineering, Faculty of mineral technology, Yogyakarta National Institute of Technology,
\end{abstract}

\begin{abstract}
PT. Bungo Bara Utama is a coal mining company that uses the open-pit mining method. Dismantling of overburdens in the form of sandstone and clay stones using ANFO explosives. Drilling and blasting are effective means of demolition activities. This method aims to unload the excavated material from the source rock and move the crushed excavated material into a pile of material ready to be loaded into the transportation means. When the explosion occurs, not all of the energy produced is used to form rock fragments. Some energy is continued in the rock mass in waves after this, referred to as seismic waves. Seismic waves due to blasting are felt as ground vibrations (Ground Vibration). PPV is the maximum speed used in measuring the magnitude of vibrations in a location depending on the distance from the location of the explosion and the number of explosives used per period. It can be concluded that to get an optimal filling with a PPV value $\leq$ of $0.8 \mathrm{~mm} / \mathrm{s}$ for a distance of $500 \mathrm{~m}$, fill in the contents ranging from $5.78 \mathrm{~kg}$ to $5.98 \mathrm{~kg}$, with a distance of $1000 \mathrm{~m}$ with entries ranging from $22.93 \mathrm{~kg}$ to $23.94 \mathrm{~kg}$, with a distance of $1300 \mathrm{~m}$ is the amount of stuffing ranging from $38.61 \mathrm{~kg}$ to $40.45 \mathrm{~kg}$, while for a distance of $1500 \mathrm{~m}$, the amount of stuffing starts from $51.31 \mathrm{~kg}$ up to a maximum filling of $53.86 \mathrm{~kg}$.
\end{abstract}

Keywords: Drilling, Ground vibration, PPV, Scaled Distance

\section{Introduction}

Indonesia is a country that exports 70 to 80 percent of total coal production(Ministry of Energy and Mineral Resources, 2014).In the related export activity, coal is a commodity that generates the largest foreign exchange for the State. PT Bungo Bara Utama is one of the mining owners who also contributes to exploiting coal to support national energy security, thus supporting the country's economy, more precisely at the Tanjung Belit site, Jujuhan District, Bungo Regency, Jambi Province. In carrying out mining activities, PT. Bungo Bara Utama (BBU) uses the open pit method because the condition of the coal deposits is located near the surface, or the SR value is still economical to be mined using the open-pit method. namely, the mining method with the 
location and its workers and the heavy equipment used in direct contact with the outside air. (YES. Yulanda, 2020).

This study aims to obtain the optimal mass of explosives with a PPV value which still refers to the SNI at PT. BBU. In the blasting process, there is an adverse effect on the surrounding environment (ground vibration)(Minara and Yulhendra, 2020). Blasting is required if the conditions on the front contain overburden material with a ripping chart, which includes high hardness, low weathering, and the influence of boundaries and discontinuity areas such as distance, continuity, separation distance, and solid orientation for excavations that have been was done using the Hitachi EX 1900 digger.

Among the harmful effects of blasting activities that often cause complaints by residents is ground vibrations. We all know that generally, there are many blasting areas close to buildings and community dwellings. From the level of ground vibration, this will affect the surrounding environment. Settlements are relatively close to the blasting area, so it is necessary to plan the blasting properly so that the shaking of the ground does not cause damage to residential buildings, which will be detrimental to the company. (Yodokus Yudiwan, 2016).

One of the mining sites affected by ground shaking is the Tanjung Belit site, Jujuhan District, Bungo Regency, Jambi Province, whose location is $500-1,300 \mathrm{~m}$ from the location. This distance is quite close to the explosion site, where the minimum distance is where the blasting activity is. According to PermenLH RI No. 04 of 2012, residents' houses are $500 \mathrm{~m}$, some of which produce a vibration level that creates both concern and claims from the surrounding community, such as the case that occurred in 2012 at the KIM site. (Roy Andre, 2012).

The SNI used for blasting vibration level standards in mining activities in buildings refers to SNI 7571: 2010 made by BSN. With SNI 7571: 2010, so as a result of this, open mining companies in Indonesia already have guidelines to control the impact of blasting activities carried out(RUDINI, 2012).

Based on the problems above, and with the existence of a typical value of blasting vibration level according to SNI 7571:2010, which BSN made, a study is needed to determine the optimal period of explosives according to this in order to reduce ground vibration.

\section{Research Method}

The research method used is observative, namely direct research into the field. Using this method is to understand better the situation and suitability with the problems in the field. Various data obtained from the field are combined with the relevant theory so that from the two parts, a problem-solving pattern is obtained. (Suyanto 2015). The research procedure starts with a literature study followed by field observations. They are collecting data in this study using primary and secondary data.

Primary data is data that the author can directly be based on field observations with the guidance of field supervisors and related employees. Primary data collected such as 1) Blasting geometry, 2) Number of explosives per hole (hole), 3) Vibration measurement results (PPV value), 4) Measurement distance (distance between the measuring point and the location of the explosion) 
Secondary data is supporting data to complement the preparation of research reports obtained from PT. Bungo Bara Utama (BBU) includes: 1) Map of company location, 2) Map of mining situation, 3) Geological map, 4) Mining system used, 5) Equipment used, 6) Specifications of blasting equipment and equipment used, 7) Blast report.

Data processing

Primary and secondary data processing, using shot plus computer software from Orica to determine the number of explosives that exploded simultaneously $(8 \mathrm{~ms})$. The actual data (PPV, distance, and contents of the explosives) were then calculated using the Scale Distance theory to obtain the formula for the relationship between PPV and Scaled Distance. This formula will be used to study the existing blasting methods in terms of the contents of the explosives and the prediction of the correct weight of the contents of the explosives to obtain the specified PPV value standard. However, do this whenever possible. The results of the study of the relationship will be displayed in a graph.

\section{Results and Discussion}

The circuit pattern used in the blasting at Pt Timur Pit. BBU is a Row Row pattern, while the ignition pattern used is hole by hole with a detonator delay of $100 \mathrm{~ms}$ and a delay between rows of $3000 \mathrm{~ms}$. The circuit system uses an electronic detonator system connected to the Blaster (Tool) using a Harness wire. Suppose the direction of the waves is in the same direction as the settlement. In that case, the resulting vibrations will be even more significant, so a series of detonations is made so that the direction of the waves does not approach the settlement.

The blasting circuit pattern used by PT. Bungo Bara Utama will be shown in the picture:

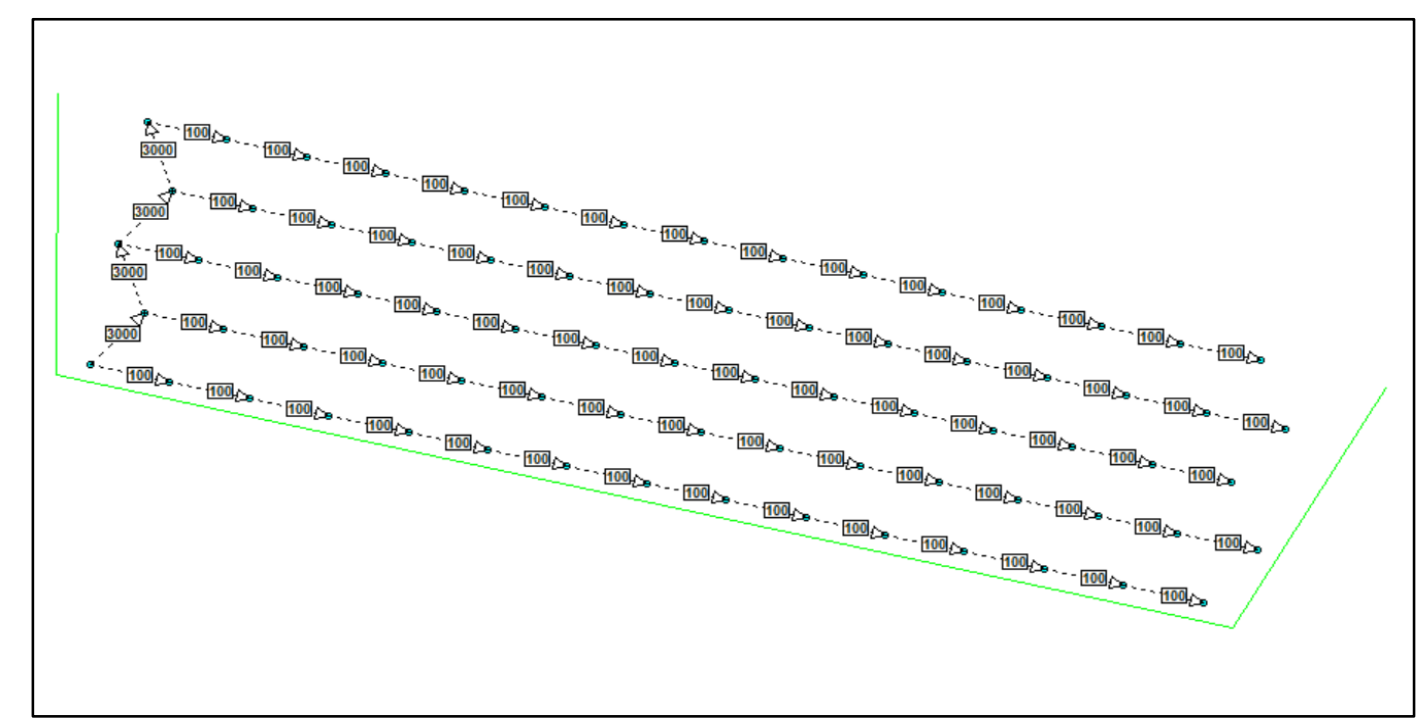

Soil Vibration Measurement Results Measurement of land resulted from the blasting of the overburden layer in various residential areas around the Tanjung Belit area. The number of ground vibration data generated is 15, and measurements were carried out in August 2020. The 
distance measurement of vibrations from the blasting location to the community is between 867 $\mathrm{m}$ to $1497 \mathrm{~m}$.

Blasting activity at the East Pit of PT. Bungo Bara Utama has an explosive hole condition with a diameter of 6.25 inches $(159 \mathrm{~mm})$. And with a sufficient depth of about $6 \mathrm{~m}-8 \mathrm{~m}$. The size of the burdens used ranged from $5 \mathrm{~m}$, and the spacing used ranged from $6 \mathrm{~m}$, while the length of the stemming fields was about $4.74 \mathrm{~m}-6.55 \mathrm{~m}$. The explosive used was ANFO with a density of $0.8 \mathrm{gr} / \mathrm{cc}$.

The results of this soil measurement consist of peak particle velocity (PPV) measurements with three types of waves produced, namely transverse, longitudinal, and vertical waves read by the blastmate III tool. The data from the measurement of ground vibrations are accompanied by the number of entries and the measurement distance, and the scale distance value.

Scale distance(SD) is a factor that affects ground vibrations which can be divided by the distance of measurement divided by the root of the amount of stuffing explosives per time delay. The scale distance affects the peak particle velocity value produced in an explosion. The following are the results of the calculation of the scale distance from the results of vibration measurements carried out on August 8 to August 29, 2020, with varying measurement distances and different numbers of entries.

Table of Calculation of Scale Distance Measurement Result for East Pit Vibration of PT. Bungo Bara Utama.

\begin{tabular}{|c|c|c|c|c|c|c|c|c|}
\hline \multirow[t]{2}{*}{ Date } & Location & $\begin{array}{c}\text { Explosion } \\
\text { hole } \\
\text { depth }\end{array}$ & Distance & $\begin{array}{l}\text { Fill / } \\
\text { Delay }\end{array}$ & PPV & $\mathrm{PF}$ & \multirow[t]{2}{*}{ Hole } & \multirow[t]{2}{*}{ SD } \\
\hline & & $\mathrm{m}$ & $\mathrm{m}$ & $\mathrm{Kg}$ & $\begin{array}{c}\mathrm{mm} \\
/ \mathrm{s}\end{array}$ & $\begin{array}{l}\mathrm{Kg} / \\
\mathrm{Bcm}\end{array}$ & & \\
\hline $\begin{array}{c}\text { Saturday, } \\
08 / 08 / 2020\end{array}$ & East Pit & 6.1 & 1,357 & 15 & 0.35 & 0.08 & 86 & 350,376 \\
\hline $\begin{array}{c}\text { Sunday, } \\
09 / 08 / 2020\end{array}$ & East Pit & 6.04 & 1,441 & 20 & 0.33 & 0.11 & 80 & 322,217 \\
\hline $\begin{array}{c}\text { Monday, } \\
10 / 08 / 2020\end{array}$ & East Pit & 6 & 1,204 & 15 & 0.41 & 0.08 & 85 & 310,871 \\
\hline $\begin{array}{c}\text { Tuesday, } \\
11 / 08 / 2020\end{array}$ & East Pit & 6 & 1,362 & 20 & 0.35 & 0.11 & 86 & 304,552 \\
\hline $\begin{array}{l}\text { Wednesday, } \\
12 / 08 / 2020\end{array}$ & East Pit & 7,8 & 1,427 & 30 & 0.46 & 0.13 & 50 & 260,533 \\
\hline $\begin{array}{c}\text { Thursday, } \\
13 / 08 / 2020\end{array}$ & East Pit & 8 & 1,497 & 32 & 0.48 & 0.13 & 71 & 264,635 \\
\hline $\begin{array}{c}\text { Saturday, } \\
15 / 08 / 2020 \\
\end{array}$ & East Pit & 7.76 & 1,288 & 30 & 0.73 & 0.13 & 72 & 235,156 \\
\hline $\begin{array}{c}\text { Tuesday, } \\
18 / 08 / 2020\end{array}$ & East Pit & 5.79 & 994 & 20 & 0.88 & 0.12 & 58 & 222,265 \\
\hline $\begin{array}{c}\text { Wednesday, } \\
19 / 08 / 2020\end{array}$ & East Pit & 6 & 944 & 20 & 0.51 & 0.11 & 24 & 211,085 \\
\hline $\begin{array}{l}\text { Wednesday, } \\
19 / 08 / 2020\end{array}$ & East Pit & 8 & 1,277 & 28 & 0.59 & 0.12 & 35 & 241,330 \\
\hline $\begin{array}{c}\text { Thursday, } \\
\text { 20/08/2020 }\end{array}$ & East Pit & 8 & 1,244 & 30 & 0.89 & 0.13 & 67 & 227,122 \\
\hline
\end{tabular}




\begin{tabular}{|c|c|c|c|c|c|c|c|c|}
$\begin{array}{c}\text { Sunday, } \\
23 / 08 / 2020\end{array}$ & East Pit & 8 & 957 & 23 & 0.9 & 0.10 & 92 & 199,548 \\
\hline $\begin{array}{c}\text { Monday, } \\
24 / 08 / 2020\end{array}$ & East Pit & 8 & 877 & 23 & 1,1 & 0.10 & 78 & 182,867 \\
\hline $\begin{array}{c}\text { Tuesday, } \\
25 / 08 / 2020\end{array}$ & East Pit & 6 & 867 & 15 & 0.73 & 0.08 & 67 & 223,858 \\
\hline $\begin{array}{c}\text { Saturday, } \\
29 / 08 / 2020\end{array}$ & East Pit & 8 & 1,029 & 30 & 0.81 & 0.13 & 73 & 187,869 \\
\hline
\end{tabular}

Ground Vibration Analysis Ground Vibration produced by blasting activities with different amounts of explosives measured at different distances will result in unequal peak particle velocity. Various factors can affect ground vibrations in the field, namely the distance from the location to the place close to the settlement, the maximum explosive content/delay, the blasting geometry, and the power factor.

Distance From Blasting Site to Measurement Location Blasting activities carried out on different amounts of explosive loads then measured the peak part velocity at different distances from the blasting location to the exact location will produce a different PPV. On measurements on August 8, 2020, and August 9, 2020, the distances were 1.357m and 1.441m, and the contents of the explosives per delay were $15 \mathrm{~kg}$ and $20 \mathrm{~kg}$, the PPV values were $0.35 \mathrm{~mm}$ $/ \mathrm{s}$ and $0.33 \mathrm{~mm} / \mathrm{s}$, respectively. Thus, it can be concluded that blasting with different explosives contents and different distances produces different PPVs.

Maximum Explosives Fill Per Delay Blasting activities that generate ground vibrations are due to the number of explosive loads per time delay. The strength of the Ground Vibration is very dependent on the maximum weight of the explosives that explode simultaneously at intervals of time. The more the explosive charge per time delay, the magnitude of the vibrations generated will increase. Such as blasting activities in the eastern pit of PT. Bungo Bara Utama on 23 and 24 August 2020, the contents of the explosives/delay were $23 \mathrm{~kg}$ but had different distances, namely $957 \mathrm{~m}$ and $877 \mathrm{~m}$, the PPV values were $0.9 \mathrm{~mm} / \mathrm{s}$ and $1.1 \mathrm{~mm}$ / s, respectively. Thus, the blasting with the same weight per delay and the closer the distance will produce a larger PPV.

Effect of Powder Factor on Ground Vibration Likewise, the powder factor used will significantly affect ground vibrations. If it is relatively small, it can produce a risky ground vibration because the energy cannot break down the rock. Likewise, suppose the power factor is relatively significant. In that case, it can result in a risky ground vibration due to the use of explosives that exceeds the capacity (far beyond the limit required to break rock). For example, a PF of 0.08 with a distance of $1.357 \mathrm{~m}$ will produce a PPV of $0.35 \mathrm{~mm} / \mathrm{s}$, and a PF of 0.13 with a distance of $1.244 \mathrm{~m}$ will produce a PPV of $0.89 \mathrm{~mm} / \mathrm{s}$. It can be concluded that a PF that is too large will produce a significant vibration Ground Vibration Level Criteria Referring to SNI 7571: 2010 and Standard PT. Bungo Bara Utama

Based on the safety criteria stipulated by SNI 7571: 2010, the buildings in the vicinity of the blasting site are categorized as category two buildings (buildings with masonry and cement mortar foundations, including buildings with wooden foundations and mortar floors) have a PPV value limit of $2 \mathrm{~mm}$. / s, wherein each ground vibration measurement the PPV value ranges from $0.33-1.1 \mathrm{~mm} / \mathrm{s}$. Even though the resulting ground vibration level met the SNI 7571: 2010 standard, many residents protested regarding the vibrations arising from the blasting 
operation. Therefore, PT. Bungo Bara Utama has set a value for ground vibration of $\leq 0.8$ to reduce complaints from residents.

Relationship between Scaled Distance and Ground Vibration Level The particle velocity of the vibration will decrease if the distance between the blast site and the vibration measurement is further away with the number of explosives per time delay, which is relatively the same. Therefore, if the distance where the explosion is measured, the farther the vibration will be, the smaller the vibration will be. In the Scale Distance formula, the factors that most influence the PPV value are the contents of the explosives and the measurement distance.

The correlation between distance and ground vibration (PPC) generated in Table 5.1 can show that the farther the distance between the blasting site and the measuring site is, the smaller the resulting ground vibration will be. This correlation strengthens the theory regarding the relationship between the distance and the number of explosives, and the ground vibrations generated during the blasting activity.

The use of the number of explosives can be optimized by researching the distribution of the weight of the explosives per time delay and the relationship between the distance to the magnitude of ground vibrations produced by an explosive activity or what is called scale distance. One of the techniques used in determining the causal correlation between one variable and another is by using regression analysis. This analysis has been used extensively in PPV analysis because the regression method can predict constants in the PPV equation. The PPV value is the dependent variable, and the scaled distance is the independent variable. The graph between the actual PPV ground vibration and the SD value shows the relationship between these two variables.

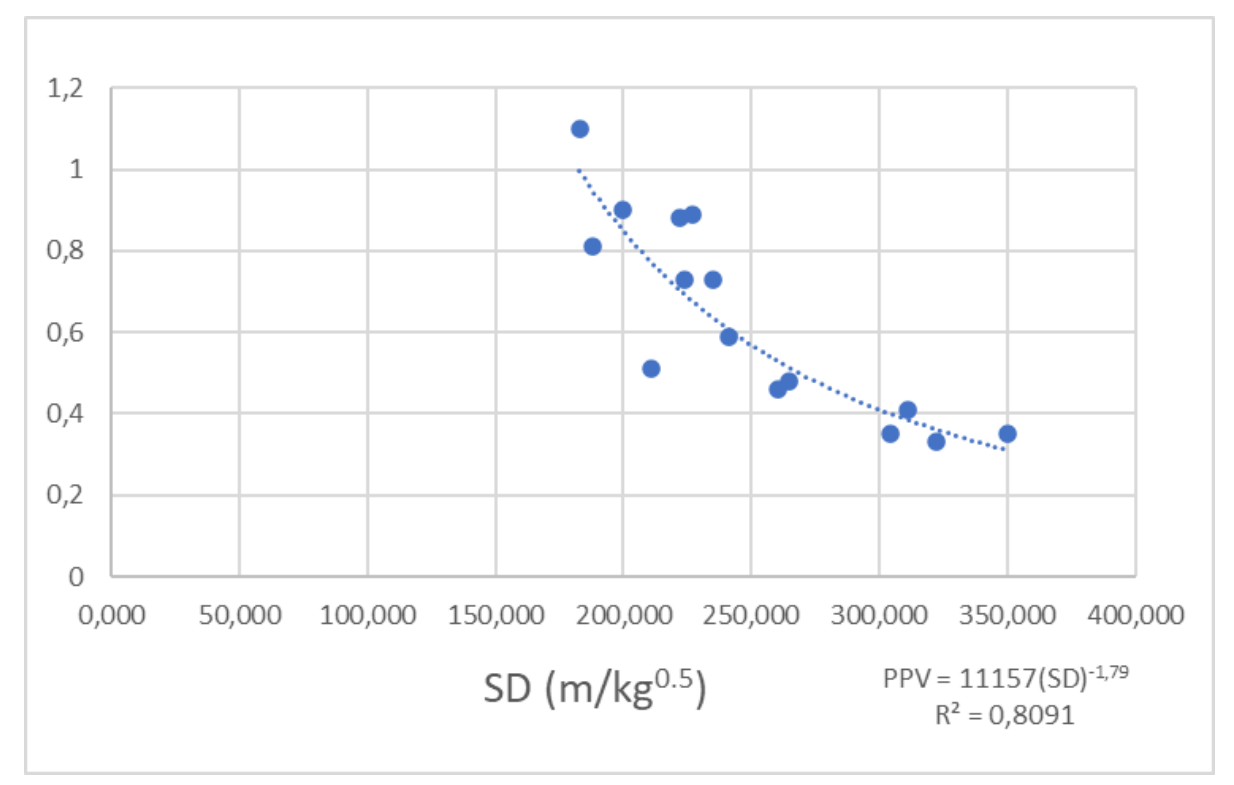

Figure 1 Graph of the Relationship between Scaled Distance and PPV 
The data from the measurement results need to be adjusted to the curve to be used because the adjustment provides a mathematical picture of the correlation of the two variables used. From the equation, the curve obtained can be used in predicting the price of the dependent variable at a point. The curve that fits the PPV and scaled distance measurement data is the power rank curve because the initial form of the PPV equation is a form of power function $(y=a x b)$. Besides the graph comparison using linear curves and power curves in determining mathematical equations to predict vibration values soil with regression analysis method.

The analysis of the relationship between SD and actual PPV was obtained from the results of vibration measurements in the field. Based on the measurement results at the time the research was taking place, it was found that the maximum PPV was $1.1 \mathrm{~mm} / \mathrm{s}$ where the measurement results were within the threshold set by the company, which was $0.8 \mathrm{~mm} / \mathrm{s}$.

From the graphic image above, a regression equation is obtained, which is an equation of the relationship between PPV and scaled distance so that the regression equation becomes PPV = 11157 (SD) - 1.79, the coefficient of determination (R2) from the data analysis shows 0.8091 , it shows if the actual PPV occurs because of the influence of the scaled distance around $80.91 \%$. In contrast, others are caused by other factors such as the characteristics and properties of rock mass and other geological factors. The constants obtained in the equation for the estimated PPV value are $\mathrm{K}=11157$ and $\mathrm{m}=-1.79$. The constant $\mathrm{K}$ value can also be obtained by using manual calculations, which are often used by using the formula $\mathrm{K}=$ then averaged. PPV/ $(\mathrm{SD}) \rrbracket \wedge(-$ 1,6) Based on the calculations from 15 PPV data and scale distance, the average constant $\mathrm{K}$ value obtained from this manual calculation is $\mathrm{K}=3,979,555$ with the constant $(\mathrm{m})$ used $\mathrm{m}=$ 1,6 .

\section{Ground Vibration Prediction}

The prediction of vibrations is made by a correlation curve between ground vibration and SD, reflecting the characteristics of the vibration decay in the rock mass towards residential areas. The prediction of vibration is known using PPV based on the formula:

$\mathrm{PPV}=\mathrm{k}\left(\mathrm{D} /\left(\mathrm{W}^{\wedge} 0.5\right)\right)-\mathrm{m}$

Note: PPV = Explosive Vibration

$\mathrm{W} \quad=$ Amount of explosives / delay

D $\quad=$ The distance between the source of the explosion and the measurement location

$\mathrm{K}=$ Constant, which is influenced by the characteristics of the rock type

explosive and local geological conditions

$\mathrm{m} \quad=$ Characteristic constant of blasted rock

In this study, the constant value $(\mathrm{K})$ that the authors use is under The power regression analysis that has been obtained is $\mathrm{K}=11157$. Furthermore, the constant value $(\mathrm{K})$ obtained from the average manual calculation is $K=3979.555$. Furthermore, the constant value $(\mathrm{m})$, which can be analyzed by power regression, is -1.79 , and the constant $(\mathrm{m})$ used in manual calculations is -1.6. These results can be obtained from 15 existing field data. Study of Soil Vibration Levels to Determine the Optimal Amount of Fill with a PPV value of $0.8 \mathrm{~mm} / \mathrm{s}$ within a distance of 500 $\mathrm{m}-1500 \mathrm{~m}$. Using the equation obtained, the prediction of the value of the ground vibration level can be carried out by adjusting the value per delay with the scaled distance formula so that the optimum filling can be obtained with a predetermined distance. Based on the same formula, the calculation of the value $(\mathrm{K})$ was carried out in the data obtained from August 8, 2020, to August 29, 2020. The value (K) of the power regression analysis was $K=11157$, and the value of the manual calculation which averaged $K=3979,555$. Based on the calculation of the value 
(K) and the vibration safety limit determined by the company, which is $0.8 \mathrm{~mm} / \mathrm{s}$, it is used in the search for the optimal value for the estimated content of explosives safe PPV value. The optimal can for getting PPV $\leq 0.8 \mathrm{~mm} / \mathrm{s}$ for a distance of $500 \mathrm{~m}$ is with entries ranging from $5.78 \mathrm{~kg}$ to $5.98 \mathrm{~kg}$, a distance of $1000 \mathrm{~m}$ is with entries ranging from $22.93 \mathrm{~kg}$ to $23.94 \mathrm{~kg}$, while the distance of $1500 \mathrm{~m}$ is the amount of stuffing ranging from $51.31 \mathrm{~kg}$ to $53.86 \mathrm{~kg}$.

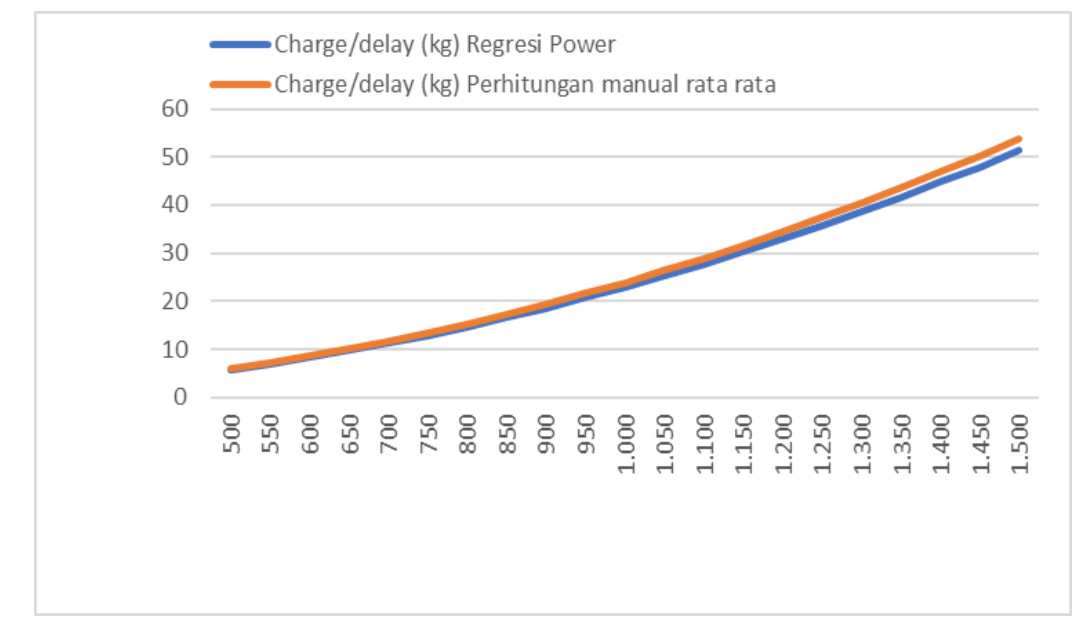

Figure 2. Image Comparison of Charge/delay with the constant value from power regression analysis and manual calculation.

\section{Conclusion}

Based on the elaboration in the discussion chapter, it can be concluded as follows;

To get the PPV value according to SNI standards and standards made by PT. BBU, namely PPV $0.8 \mathrm{~mm} / \mathrm{s}$ with a distance of $500 \mathrm{~m}-1500 \mathrm{~m}$. at a distance of $1200 \mathrm{~m}$, the required filling is $32.94 \mathrm{~kg}$ to $34.47 \mathrm{~kg}$, with a distance of $1300 \mathrm{~m}$, with entries ranging from $38.61 \mathrm{~kg}$ to $40.45 \mathrm{~kg}$, with a distance of $1400 \mathrm{~m}$ with the number of entries starting from $44.74 \mathrm{~kg}$ to 46.92 $\mathrm{kg}$, while for a distance of $1500 \mathrm{~m}$ the amount of filling starts from $51.31 \mathrm{~kg}$ up to a maximum filling of $53.86 \mathrm{~kg}$. Various factors affect the level of ground vibration, including the amount of charge per delay and the distance between the measurements from the explosion location. The more explosives are used per hole, the greater the level of ground vibration is generated. The farther distance the vibration level is measured from the blast site, the smaller the ground vibration level will be obtained. Referring to the SNI 7571: 2010 vibration standard, blasting operations were carried out in the eastern pit of PT. Bungo Bara Utama is quite good. Buildings in residential areas, including those in class 2, have a PPV value limit of $2 \mathrm{~mm} / \mathrm{s}$. For each ground vibration measurement activity, the PPV value obtained ranges from $0.33 \mathrm{~mm} / \mathrm{s}$ to 1.1 $\mathrm{mm} / \mathrm{s}$. 


\section{References}

[1.] National, DE (2014). Indonesia Energy Outlook 2014. Jakarta (ID): Ministry of Energy and Mineral Resources of the Republic of Indonesia.

[2.] Minara, Y., \& Yulhendra, D. (2020). Analysis of Reduction in Ground Vibration from Overburden Blasting at PT Kalimantan Prima Persada Jobsite HJUR Pit Agathis, Rantau, South Kalimantan. Bina Tambang, 5 (5), 78-88.

[3.] Yudiwan, Yodokus, Nugroho, Windhu \& Trides, Tomy, 2016, Analysis of Ground Vibration Due to Blasting at Pit Kinong, PT Firman Kataun Perkasa, Melak District, West Kutai Regency, East Kalimantan. Journal of Technology, FT UNMUL. Vol. 4, No. 1, pp. 47-53.

[4.] Andre, Roy, 2012, Mess Employees of PT. Kim destroyed by Citizen, Globalsumut.com. (viewed on March 8, 2020).

[5.] RUDINI, RUDINI. GROUND VIBRATION ANALYSIS ON OVERBURDEN EXPLOSION IN PANEL 4 PIT J PT. KALTIM PRIMA COAL, SANGATTA, KALIMANTAN TIMUR. Diss. UPN "Veteran" Yogyakarta, 2012.

[6.] Suyanto, Bagong. Social Research Methods: Various Alternative Approaches. Grenada Media, 2015.

[7.] Yulanda, YA., Toha, \& Sjarkowi, F., 2020, Optimization of stripping ratio with the discounted cash flow method in the mine-mouth power plant project. Mining Journal. Vol. 4, No. 3, ISSN. 2549-1008. 